\title{
Studies in genera similar to Torula: Bahusaganda, Bahusandhika, Pseudotorula, and Simmonsiella gen. nov.
}

\author{
J. Leland Crane ${ }^{1}$ and Andrew N. Miller ${ }^{1}$
}

${ }^{1}$ Illinois Natural History Survey, University of Illinois, 1816 S. Oak St., Champaign, IL 61820, USA; corresponding author e-mail: amiller7@illinois. edu

Abstract: A generic key is presented to delimit Torula from seven hyphomycete genera whose type species were at one time included in the genus or whose conidium ontogeny and conidium development appear similar or superficially similar to that of Torula herbarum, the type of the genus. In Bahusaganda, two new species are described (B. elliseverhartii and B. simmonsii spp. nov.) and three new combinations made (B. ambrosiae, B. elaeodes, and B. heteromorpha combs. nov.). In Bahusandhika, one new species (B. hughesii sp. nov.) is introduced, and two new combinations made ( $B$. rhombica and $B$. terrestris combs. nov.), along with emendations in the circumscription of $B$. caligans and $B$. intercalaris. Latorua is considered synonymous with Bahusandhika. In Pseudotorula, one new combination is made ( $P$. sundara comb. nov.), and one emendation proposed ( $P$. helica). The transfer of Dwayabeeja sundara, the type species of the genus, to Pseudotorula will require a new generic name to be introduced for $D$. aethiopica and $D$. cubensis. The new generic name Simmonsiella is established for Torula ndjilensis. Bahusandhika compacta is shown to be synonymous with Torula verrucospora.
Key words: Bahuchashaka corona cell Dwayabeeja Latorua Polyschema

Article info: Submitted: 13 August 2015; Accepted: 3 February 2016; Published: 16 February 2016.

\section{INTRODUCTION}

The genus Torula, typified by T. herbarum, is characterized by terminal or lateral, monoblastic or polyblastic conidiogenous cells which have a basally thickened and heavily melanized wall, with the apex thin-walled and frequently collapsing and becoming coronate; these conidiogenous cells are consequently termed 'corona cells'. The corona cell may be sessile on hyphae or arise on micronematous conidiophores. A discussion of the conidiogenesis in Torula, with light and transmission electron microscopy was provided by Crane \& Schoknecht (1977). Melanized, verrucose, phragmoconidia are produced acropetally in simple or branched chains from monoblastic or polyblastic corona cells. The terminal cell of a conidium may become conidiogenous and coronate. These characters, were used to segregate Torula, and observed by Mason (1941), Hughes (1953), Subramanian (1971), and Ellis (1971, 1976). In this paper, several hyphomycete species previously placed in Torula were re-examined and found not to be congeneric with $T$. herbarum; and these are transferred to more appropriate genera.

Additionally, Torula rhombica and T. terrestris are transferred to Bahusandhika with the addition of a new species. The descriptions of Bahusanhika caligans and B. intercalaris are emended. Bahusanhika is characterized by having conidia in chains but lacking coronate, conidiogenous cells. Brief diagnoses of Bahusaganda, Bahusandhika, and Torula, with illustrations of their type species, are found in Seifert et al. (2011). Torula ndjilensis is placed in the new genus,
Simmonsiella, based on the first formed conidia giving rise to a series of intercalary phragmoconidia. Bahusandhika compacta is shown to be synonymous with Torula verrucospora. Crous (2015) revised the family Torulaceae and included the genera Dendryphion and Torula. In the genus Torula, he established three new species based on the number of septa per conidium and re-established $T$. monilis, a Persoon name previously considered a synonym of $T$. herbarum by Hughes (1958), as distinct based on the conidia having as many as nine septa, but this species predominantly has 3-septate conidia and the lower chain of cells occasionally becomes muriform. Crous (pers. comm.) suggested that Deightoniella indica, the type of Bahusaganda, belongs in Torula s. str. The conidiogenous cells of both genera are corona cells, but the conidia of Torula are catenate while those of Bahusaganda are borne solitarily so we consider the two genera as distinct.

\section{MATERIALS AND METHODS}

Dried specimens of the fungi treated in this paper were obtained from the following fungaria: BPI, CBS, DAOM, ILL, ILLS, IMUR, K (incl. IMI), L, NY, NYS, and W. Microscopic specimens were rehydrated in distilled water and mounted on microscopic slides with a No. 1 cover slip. Permanent mounts were made in lactophenol and stained with acid fuchsin. Measurements were made from water or lactophenol mounts. All observations and measurements were made with a Zeiss Universal compound microscope equipped with brightfield,

\section{() 2016 International Mycological Association}

You are free to share - to copy, distribute and transmit the work, under the following conditions:

Attribution: $\quad$ You must attribute the work in the manner specified by the author or licensor (but not in any way that suggests that they endorse you or your use of the work).

Non-commercial: $\quad$ You may not use this work for commercial purposes.

No derivative works: You may not alter, transform, or build upon this work.

For any reuse or distribution, you must make clear to others the license terms of this work, which can be found at http://creativecommons.org/licenses/by-nc-nd/3.0/legalcode. Any of the above conditions can be waived if you get permission from the copyright holder. Nothing in this license impairs or restricts the author's moral rights. 

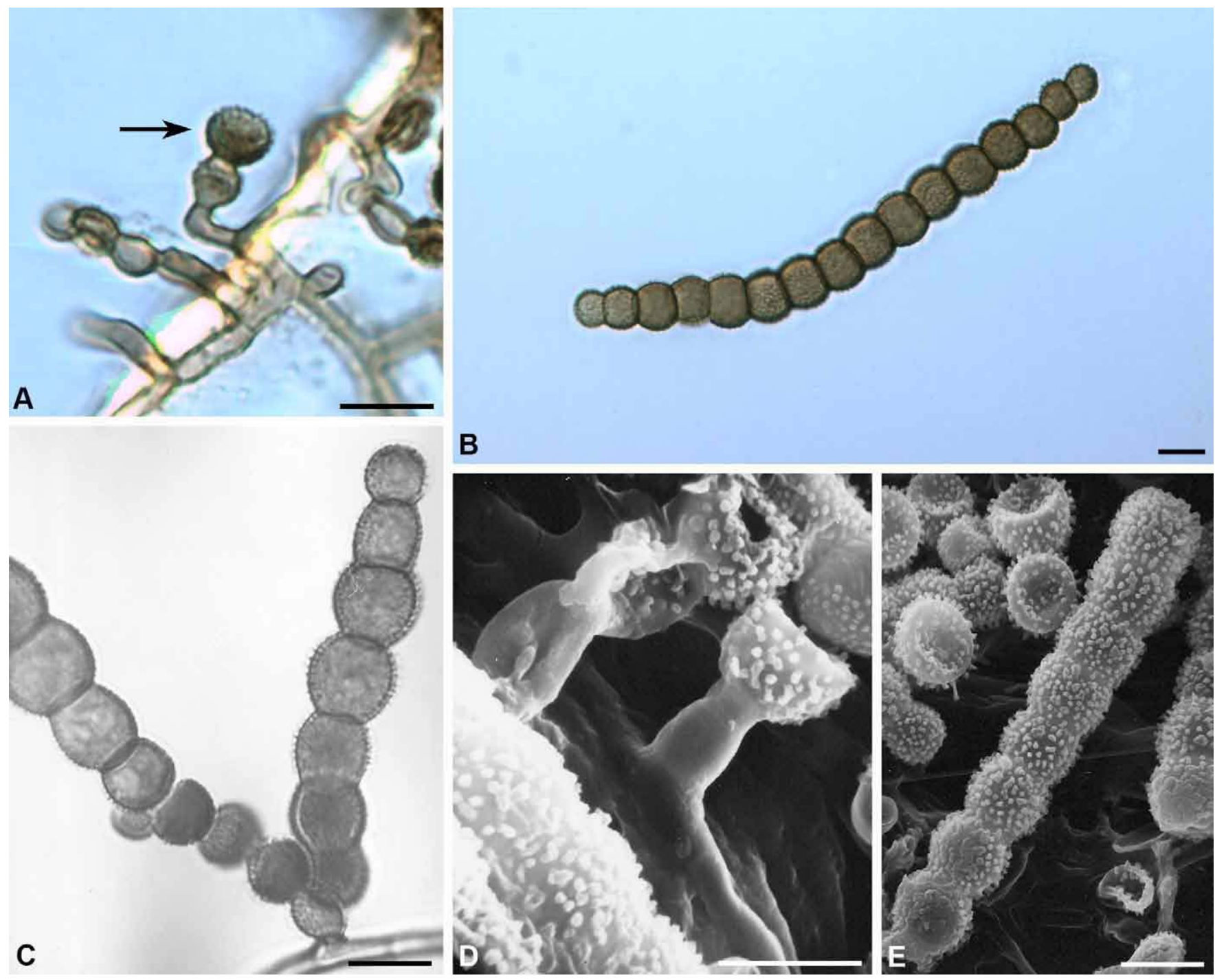

Fig. 1. Bahusaganda ambrosiae. A. Coronate conidiogenous cell (arrow) (Bartholomew 3508, holotype). B. Mature conidia (ILLS 59071). C. Polyblastic conidiogenous cell and two developing conidia (ILLS 59071). D. Corona cell on a stalk cell developing laterally on a hypha (Bartholomew 3508, holotype). E. Mature verrucose conidium (Bartholomew 3508, holotype). Bars $=10 \mu \mathrm{m}$.

phase, and Nomarski optics. The line drawing was prepared using a Camera Lucida on a Wild compound microscope and illustrated using India ink.

Images of micromorphological structures were captured with a QImaging QColor 3 digital camera mounted on an Olympus BX51 compound microscope using differential interference microscopy. Images were processed using Adobe Photoshop CS6 (Adobe Systems, Mountain View, CA). A minimum of 30 measurements was taken for all morphological structures whenever possible.

\section{TAXONOMY}

\section{Bahusaganda Subram.}

Proc. Indian Natl. Sci. Acad., B 60: 277 (1993).

Type species: Bahusaganda indica (Subram.) Subram. 1994.

Description: Conidiophores micronematous, arising terminally or laterally on the hyphae or reduced to a stalk cell subtending the conidiogenous cell. Conidiogenous cells coronate, solitary or catenate but uniform, monoblastic or polyblastic. Conidia lightly melanized to dark brown, phragmoseptate, moniliform to cylindric, solitary, dry.

Notes: Torula ambrosiae, T. elaeodes and T. heteromorpha are transferred to Bahusaganda, characterized by having coronate conidiogenous cells and solitary phragmoconidia. In addition, two new species are added to this genus.

Bahusaganda ambrosiae (Peck) J.L. Crane \& A.N. Mill., comb. nov.

MycoBank MB815628

(Fig. 1)

Basionym: Hormiscium ambrosiae Peck, New York State Mus. Bull. 150: 55 (1911).

Synonym: Torula ambrosiae (Peck) S. Hughes, Canad. J. Bot. 36: 818 (1958).

Description: Colonies effuse, black, somewhat appressed to the substrate. Mycelium superficial, composed of 
branched, septate, subhyaline to brown hyphae $\sim 2 \mu \mathrm{m}$ wide. Conidiophores arising laterally from the hyphae, micronematous, composed of several cylindrical to ovoid cells or reduced to an ovoid cell subtending a conidiogenous cell. Conidiogenous cells monoblastic or polyblastic, catenate, ovoid, lower portion thick-walled and melanized, apical portion subhyaline to pale brown, thin-walled, frequently collapsing and becoming coronate, 5.5-7 $\mu \mathrm{m}$ wide. Conidia solitary, cylindrical or slightly curved, tapering at each end, brown, verrucose, variable in length and septation, composed of moniliform cells, $(40-) 55-110(-140) \times(6-) 8-13(-14.5)$ $\mu \mathrm{m}, 6-15$-septate.

Type: USA: Kansas: Pottawatomie County, Louisville, on [dead stems of] Ambrosia trifida L., 39.2502 N, 96.3147 W, 26 Sept. 1906, E. Bartholomew NYS - holotype; [Bartholomew, Fungi Columb. no. 3330.] DAOM 34242, ILL - isotypes).

Additional specimens examined: USA: Illinois: Union County, Shawnee National Forest, Pine Hills at McCann Springs, on dead stalks of Impatiens pallida, 37.5874 N, 89.4366 W, 27 Aug. 2000, J.L. Crane \& J.D. Schoknecht S.n. (ILLS 56396); Jackson County, Fountain Bluff, in ravine along Happy Hollow Road, $37.6928 \mathrm{~N}$, 89.4908 W, 24 Nov. 2000, J.L. Crane 00-12 (ILLS 55487); Fountain Bluff overlook, 37.6927 N, 89.5011 W, J.L. Crane 01-241 (ILLS 59071); Calhoun County, two miles from the intersection of Rt. 100 and East Panther Creek Road, 39.3726 N, 90.6249 W, 11 Nov. 2000, Michael E. Retzer s.n. (ILLS 69255).

Notes: Bahusaganda ambrosiae is close to $B$. indica in conidial development, morphology, and the length of the conidia but differs in the conidia being composed of more globose cells with verriculose ornamentation. The conidia of $B$. indica are wider at their broadest part and have an echinulate ornamentation with echinules measuring 0.5-1 $\mu \mathrm{m}$. Bahusaganda ambrosiae is known from Kansas and Illinois on dead stems of Ambrosia trifida and Impatiens pallida.

\section{Bahusaganda elaeodes (Pound \& Clem.) J.L. Crane \& A.N. Mill., comb. nov. \\ MycoBank MB815632}

(Fig. 2)

Basionym: Clasterosporium elaeodes Pound \& Clem., Bull. Geol. Nat. Hist. Surv. Minn. 9: 661 (1896).

Synonyms: Torula elaeodes (Pound \& Clem.) S. Hughes, Canad. J. Bot. 36: 818 (1958).

Clasterosporium olivaceum Ellis \& Everh., Proc. Acad. Nat. Sci. Phil. 1893: 463 (1894); nom. illegit. (Art. 53.1); non (Wallr.) Sacc., Syll. Fung. 4: 390 (1886).

Polyschema olivacea M.B. Ellis, More Demat. Hyphom.: 372 (1976); as "(Ellis \& Everh.) M.B. Ellis comb. nov.", nom. illegit. (Arts. 58.1, 52.1).

Clasterosporium zeae Sacc. \& Syd., in Saccardo, Syll. Fung. 14: 1083 (1899).

Description: Colonies effuse, on natural substrate dark brown, in culture becoming floccose with a grey centre and a white to greyish margin. Mycelium composed of branched, septate hyphae which becomes subhyaline to light brown with age,
2-3.5 $\mu \mathrm{m}$ wide. Conidiogenous cells discrete, monoblastic, coronate, dark brown, verrucose, $4.5 \times 5.5 \mu \mathrm{m}$, arising laterally on the hyphae, sessile or occasionally subtended by a light brown, cylindrical stalk-cell measuring 4.5-7 × 2-4.5 $\mu \mathrm{m}$. Conidia blastic, solitary, cylindrical, verrucose, with 3-6 or 2-7 (Ellis 1976) transverse septa, slightly constricted at the septa, light brown to brown, distinctly dark brown at the base, $(15.5-) 20-25(-27) \times(4.5-) 5.5-7 \mu \mathrm{m}$.

Type: USA: New Jersey: Gloucester County, Newfield, on old corn stalks (Zea mays), 39.5463 N, 75.0252 W, 13 May 1893 [Pub. as 14 May 1893] (NY - holotype; DAOM 35326, ILLS 36107 [microscopic preparation] - isotypes).

Additional specimen examined: USA: Illinois: Johnson County, Forman, on dead culms of Arundinaria gigantea, in a marsh by a railroad crossing, 37.3452 N, 88.9143 W, 19 Feb. 1974, J.L. Crane s.n. (ILLS 36106).

Notes: Bahusaganda elaeodes is reported from New Jersey on Zea mays, from Illinois on Arundinaria gigantea ,and from Taiwan (as Polyschema olivacea) on Schoenoplectus triqueter (Wu et al. 1982). The species differs from $B$. simmonsii in having smaller conidia with a characteristically dark brown base.

Bahusaganda elliseverhartii J.L. Crane \& A.N. Mill., sp. nov.

MycoBank MB815634

(Fig. 3)

Etymology: Honouring Job Bicknell Ellis (1820-1905) and Benjamin Matlack Everhart (1818-1904) pioneers of the study of North American microfungi.

Diagnosis: Differs from the other species described in the genus in having monoblastic conidiogenous cells, the attachment points of conidia lacking heavy melanization and the conidia end cells subhyaline to light brown.

Type: USA: Florida: on Sabal, with Ophiobolus versisporus, Winter 1888, W.W. Calkins [Ellis \& Everhart, N. Amer. Fungi, no. 2875] (DAOM [bound set] - holotype; DAOM 237573, ILL, L 910, 250-248 - isotypes).

Description: Colonies effuse, brown, around ostioles of Ophiobolus versiporus. Mycelium composed of superficial, branched, septate, anastamosing hyphae, 1-2 $\mu \mathrm{m}$ diam. Conidiophores arising terminally or laterally on the hyphae, composed of a series of 1-7 coronate cells that may become conidiogenous. Conidiogenous cells monoblastic, thick-walled and dark brown at base, thin-walled and light brown at apex, $2-4.5 \times 3.5-4.5 \mu \mathrm{m}$. Conidia solitary, cylindrical, occasionally slightly curved, brown, end cells paler, (4-)5-7(-8)-septate, constricted at septa, (14)20-40.5 × 4.5-7 $\mu \mathrm{m}$.

Additional specimen examined: USA: Florida: Miami-Dade County, Everglades National Park, Long Pine Key Hammock 21 (Mosier), on a dead petiole of Serenoa repens, 25.4010 N, 80.6605 W, 27 Dec. 1983, J.L. Crane \& J.D. Schoknecht (ILLS 73037). 

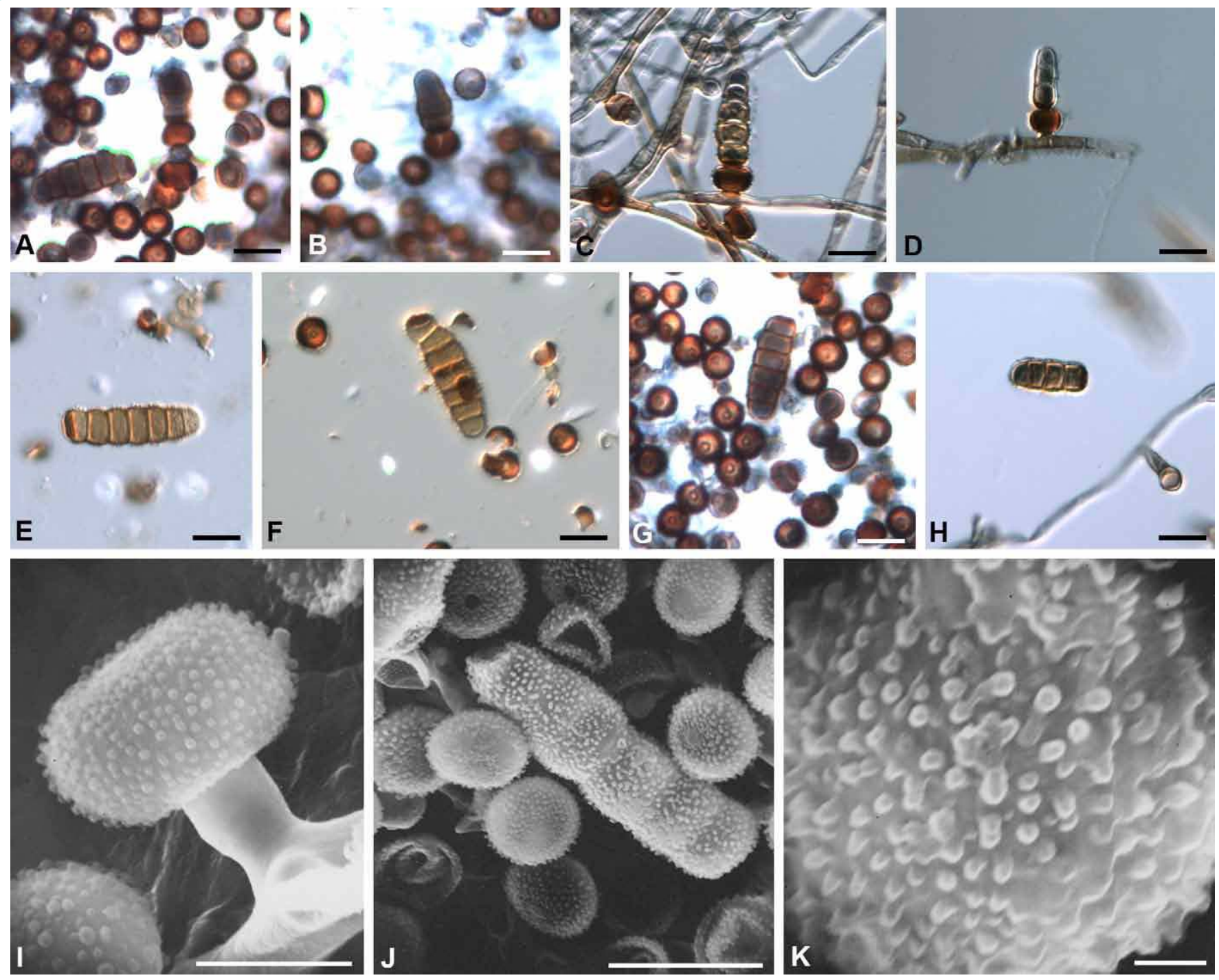

Fig. 2. Bahusaganda elaeodes. A-D. Conidiogenesis illustrating corona cells and developing conidia (ILLS 36106). C-D. Corona cells laterally attached to hyphae (ILLS 36106). E-H. Mature conidia and corona cells (holotype). I. Corona cell and subtending stalk cell laterally attached to hypha (holotype). J. Mature conidium and corona cells (holotype). K. Conidium cell illustrating verrucae (holotype). Bars: A-H \& J = $10 \mu \mathrm{m}, \mathrm{I}=$ $5 \mu \mathrm{m}, \mathrm{K}=1 \mu \mathrm{m}$.

Notes: Bahusaganda elliseverhartii differs from B. simmonsii in the conidia which are usually cylindrical, slightly constricted at the septa, and have subhyaline to pale brown end cells, while those of $B$. simmonsii are usually ellipsoidal and pale golden brown throughout.

Bahusaganda heteromorpha (Penz. \& Sacc.) J.L. Crane \& A.N. Mill., comb. nov.

MycoBank MB815635

(Fig. 4)

Basionym: Torula heteromorpha Penz. \& Sacc., Malpighia 15: 244 (1902).

Description: Colonies on natural substrate effuse, velutinous, olivaceous-brown. Mycelium composed of branched, septate, superficial, repent, light to dark brown hyphae, 2-4.5 $\mu \mathrm{m}$ wide. Conidiophores (15-)25-34(-48) $\mu \mathrm{m}$ long, basal cell cylindrical, $2 \mu \mathrm{m}$ wide, terminated with one to many spherical, thick-walled, dark brown cells, verruculose, constricted at the septa, 4.5-7(-10) $\mu \mathrm{m}$ wide which remain in simple chains or secede from the conidiophore, the terminal cell of the conidiophore becoming coronate and conidiogenous. Conidiogenous cells coronate, thick-walled and dark brown at base, thinner walled and paler at apex, monoblastic or polyblastic, verruculose, arising terminally from the basal cell or from a spherical cell, 4.5-7 × 8-9 $\mu \mathrm{m}$. Conidia solitary, echinulate, cylindrical to slightly sigmoid, (5-)7-10-septate, constricted at septa, usually tapering to the rounded end cells, $(50-) 65-78(-102) \times(10-) 13-18 \mu \mathrm{m}$.

Type: Indonesia: [Province of West Java], Tjibodas, in caulibus majoribus putridis, udis, 4 Mar. 1897, Penzig 250 (W - holotype; DAOM, ILLS 69093 - isotypes).

Additional specimen examined: Venezuela: Edo Portuguesa, road between La Estacion \& Santa Rosa del Guache, ca. 2 mi S of Santa Rosa, on mountainside with a rocky stream and a small remnant forest, on a herbaceous stem, 16 Jan. 1993, S.M. Huhndorf, F. Ortega, J.L. Crane \& J.D. Schoknecht (SMH 371, ILLS 68965). 


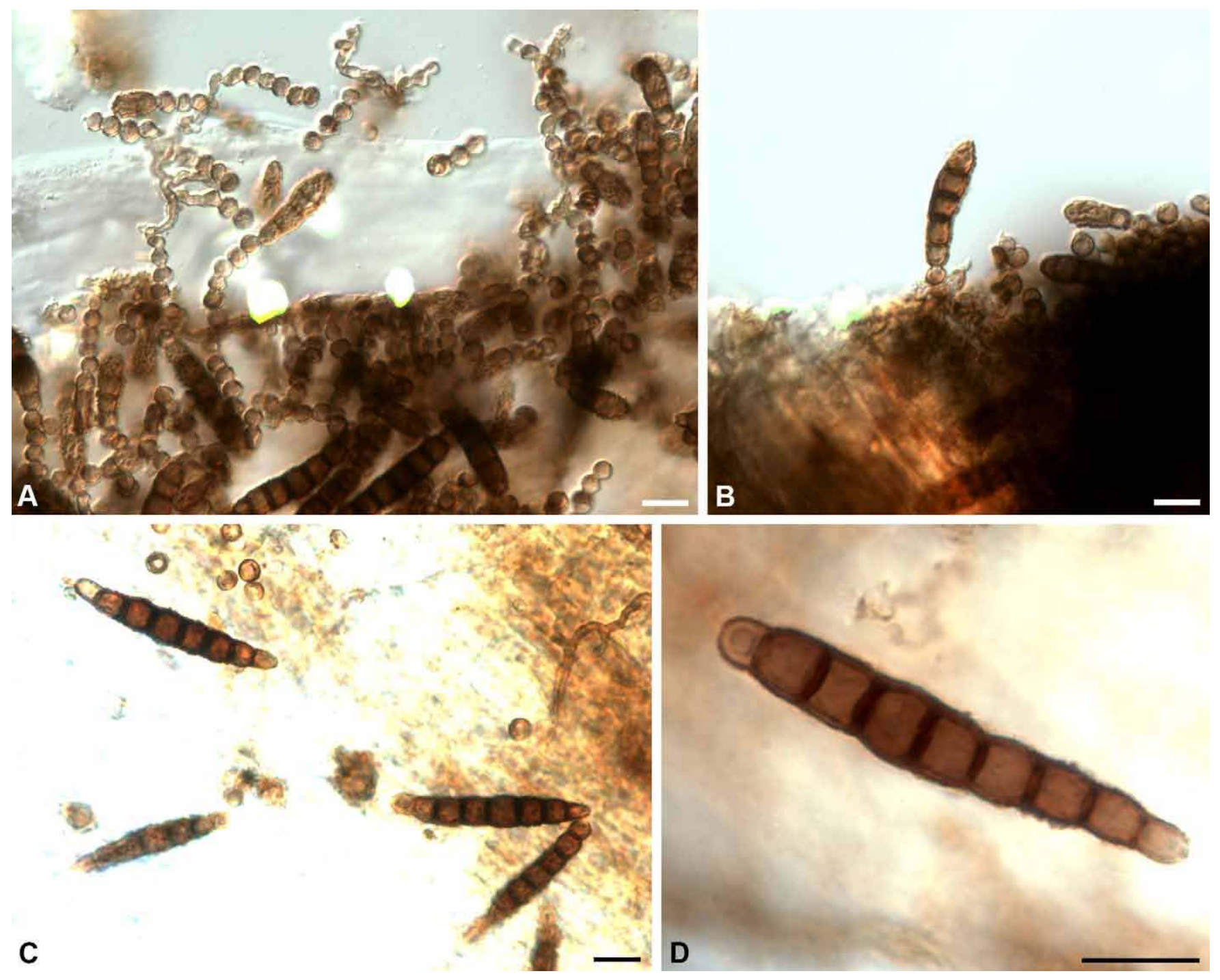

Fig. 3. Bahusaganda elliseverhartii (holotype). A-B. Conidiogenesis. A. Catenate series of corona cells with attached conidium. B. Conidia attached to corona cells. C-D. Mature conidia. Bars $=10 \mu \mathrm{m}$.

A

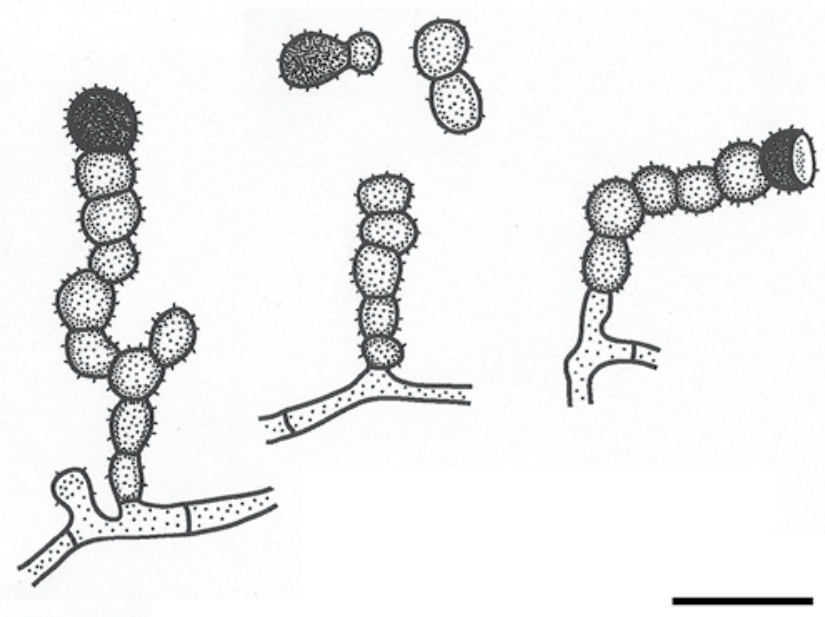



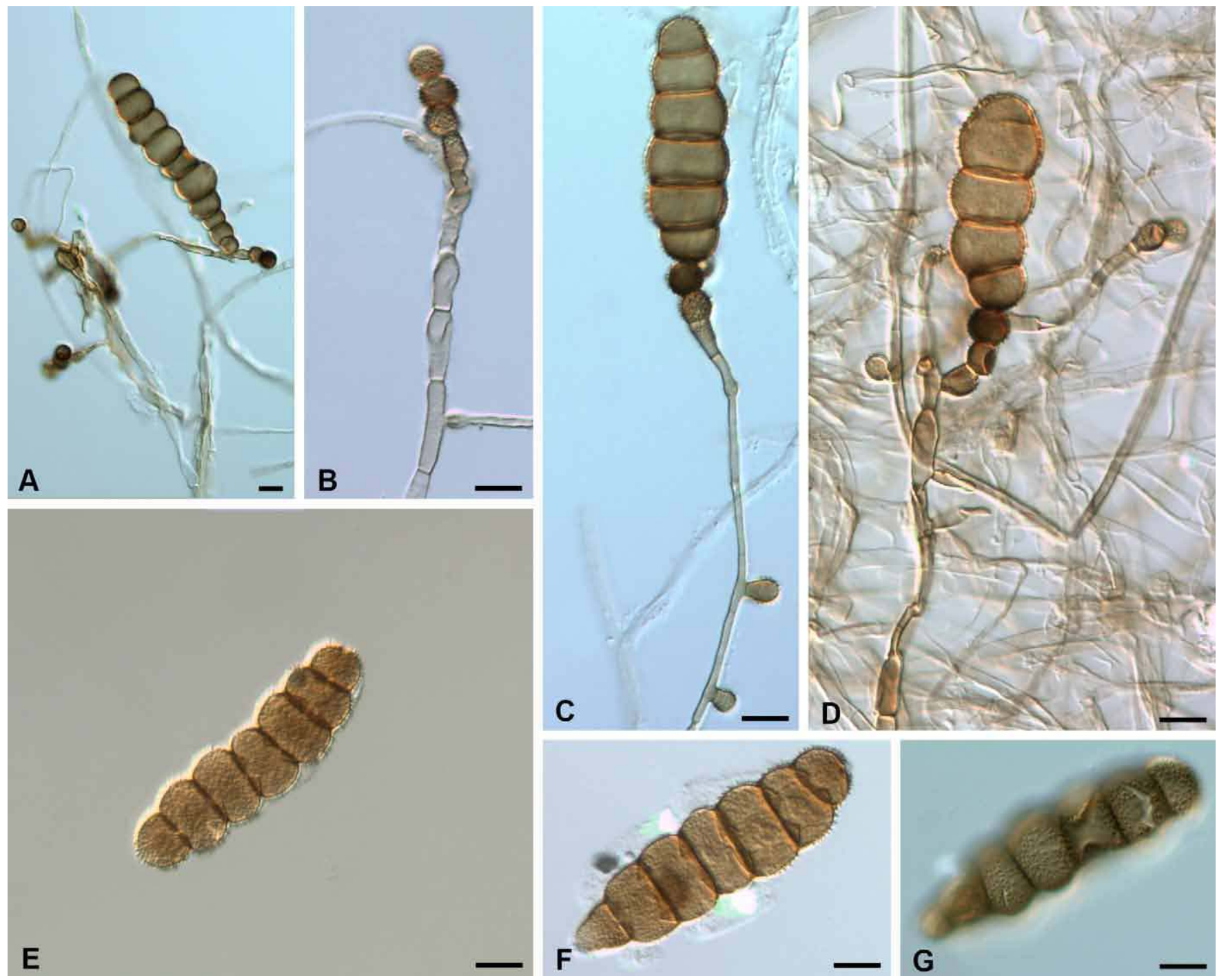

Fig. 5. Bahusaganda simmonsii (holotype). A. Mature conidium. B. Micronematous conidiophore with a mature, terminal corona cell and two laterally developing corona cells. C-D. Successive corona cells on terminal micronematous conidiophores. E-G. Mature conidia. Bars $=10 \mu \mathrm{m}$.

Note: Bahusaganda heteromorpha differs from B. simmonsii in having conidia that are echinulate and cylindrical to sigmoid, while those of $B$. simmonsii are smooth to verrucose and ellipsoid to cylindrical.

\section{Bahusaganda simmonsii J.L. Crane \& A. N. Mill., sp.} nov.

MycoBank MB815636

(Fig. 5)

Etymology: Named in honour of the collector, Emory Guy Simmons (1920-2013).

Diagnosis: Differing from other species in the genus in that the attachment point of the basal cell is not heavily melanized and all of the conidial cells are pale golden brown.
Type: Indonesia: Province of West Java: Mountain Gardens, Tjibodas, dried culture isolated from an undetermined, dead herbaceous stem, 6.4691 S, $106.6663 \mathrm{E}, 12$ Feb. 1969, E.G. Simmons QM 9540 (DAOM 237572 - holotype; ILLS 67346 [dried culture and microscopic preparations] - isotype).

Description: Colonies on agar floccose to appressed, pale brown to grey. Mycelium composed of branched, septate, brown hyphae, 2-3.5 $\mu \mathrm{m}$ wide. Conidiophores micronematous, arising terminally or laterally on the hyphae, pale brown, 2-4.5 $\mu \mathrm{m}$ wide, (1-)2-8(-10)-septate, each conidiophore terminated by 1 or $2-4$ successive, coronate, dark brown, monoblastic conidiogenous cells, 4.5-7 × (5.5-) $7(-8) \mu \mathrm{m}$. Terminal conidiophores 60-124 $\mu \mathrm{m}$ long, lateral conidiophores (10-)15-40(-48) $\mu \mathrm{m}$ long. Conidia ellipsoidal, pale golden brown, smooth to verrucose, (3-)5-7(-9)-septate, constricted at septa, 23-(35-69)-90 × 14.5-18 $\mu \mathrm{m}$.

\section{Key to the species of Bahusaganda}


2 (1) Attachment point of the basal cell of conidium heavily melanized

3(2) End cells of conidia subhyaline to light brown, conidial width 4.5-7 $\mu \mathrm{m}$

B. elliseverhartii

Cells of conidia all pale golden brown, conidial width 14.5-18 $\mu \mathrm{m}$

B. simmonsii

4 (1) Conidia to 30 -septate

5

Conidia to 15-septate

6

5 (4) Conidia fusiform-elliptical, to 30-septate

B. indica

Conidia cylindrical, to 21-septate

B. sundara

6 (4) Conidia with moniliform cells, 6-15-septate

B. ambrosiae

Conidia with central cells oblong in width, 5-10-septate

B. heteromorpha

Bahusandhika Subram., J. Indian Bot. Soc. 35: 469 (1956).

Synonym: Latorua Crous, IMA Fungus 6: 176 (2015).

Type: Bahusandhika indica (Subram.) Subram. 1956 (syn. Polydesmus indicus Subram. 1954).

Description: Colonies effuse, discrete, floccose, pulverulent or velvety, grey to dark brown, olivaceous black to black. Mycelium composed of branched, septate, smooth or verrucose, subhyaline, brown, dark brown or reddish brown hyphae. Conidiophores present or absent, when present borne terminally or laterally on the hyphae, straight or flexuous, brown, septate, with or without constrictions at the septa, sometimes reduced to a stalk cell. Conidiogenous cells monoblastic or polyblastic, uniformly thin-walled, spherical, ovoid, ampulliform, smooth or verrucose, discrete, borne terminally or laterally on hyphae or conidiophores. Conidia catenate in simple or branched chains, fusiform, cylindrical or rhomboidal, thin or thick-walled, phragmoseptate, light or dark brown, smooth or verrucose.

Notes: Based on the similarity of the conidiogenous cells, conidial development and the morphological characters of the conidia, we synonymize the genus Latorua with Bahusandhika.

Bahusandhika caligans Bat. \& H.P. Upadhyay, Atas Inst. Micol. Univ. Recife 2: 321 (1965).

(Fig. 6)

Synonyms: Torula caligans (Bat. \& H.P. Upadhyay) M.B. Ellis, Demat. Hyphom.: 337 (1971).

Latorua caligans (Bat. \& H.P. Upadhyay) Crous, IMA Fungus 6: 176 (2015).

Description: Colonies in culture effuse, velvety, grey to dark brown or black. Mycelium composed of branched, septate, smooth or verrucose hyphae 2-3.5 $\mu \mathrm{m}$ wide, at first hyaline becoming subhyaline to light brown. Conidiophores micronematous, simple or branched, septate, straight or flexuous, subhyaline to light brown, distinctly verrucose. Conidiogenous cells thin-walled, spherical, smooth or verrucose, subhyaline to light brown, monoblastic or polyblastic, borne terminally or laterally on the conidiophore, either integrated or discrete, 3-6($10) \times 2.5-6 \mu \mathrm{m}$. Conidia catenate in simple or branched chains, broadly fusiform to ellipsoidal, 1-3-septate but mostly 3-septate, constricted at the septa, verruculose to echinulate, end cells hyaline to light brown, apical end cell frequently becoming a monoblastic or polyblastic conidiogenous cell, central cells dark olivaceous brown, $15-24.5 \times 6-10 \mu \mathrm{m}$ in the broadest part.

Type: Brazil: Pernambuco: Caruaru, isolated from soil, 8.2849 S, 35.9701 W, 11 Aug. 1964, Epaminondas de Barros Correia (IMUR 1955 - holotype; DAOM, ILLS 35634 [microscopic preparation] - isotypes).

Notes: Singh et al. (1974) reported this species from soil in Bangalore, India, and noted that the conidia of the Indian material were broader than in the type. These authors also synonymized Bahusandhika with Torula. They compared the conidia of $B$. caligans with those of $T$. herbarum but made no mention of the differences in the conidiogenous cells of these two species. A new combination is made for Latorua grootfonteinensis in Bahusandhika below.

Bahusandhika grootfonteinensis (Crous) J.L. Crane \& A.N. Mill., comb. nov.

MycoBank MB815637

Basionym: Latorua grootfonteinensis Crous, IMA Fungus 6: 176 (2015).

Bahusandhika hughesii J.L. Crane \& A.N. Mill., sp. nov.

MycoBank MB815638

(Fig. 7)

Etymology: In honour of Stanley J. Hughes, mycologist par excellence.

Diagnosis: Differing from the previously described species in the genus by the conidia being verrucose and to 25 septate.

Type: New Zealand: Auckland District: Mamaku State Forest, on bark of Coprosma australis, 36.8484 S, 174.7633 E, 22 

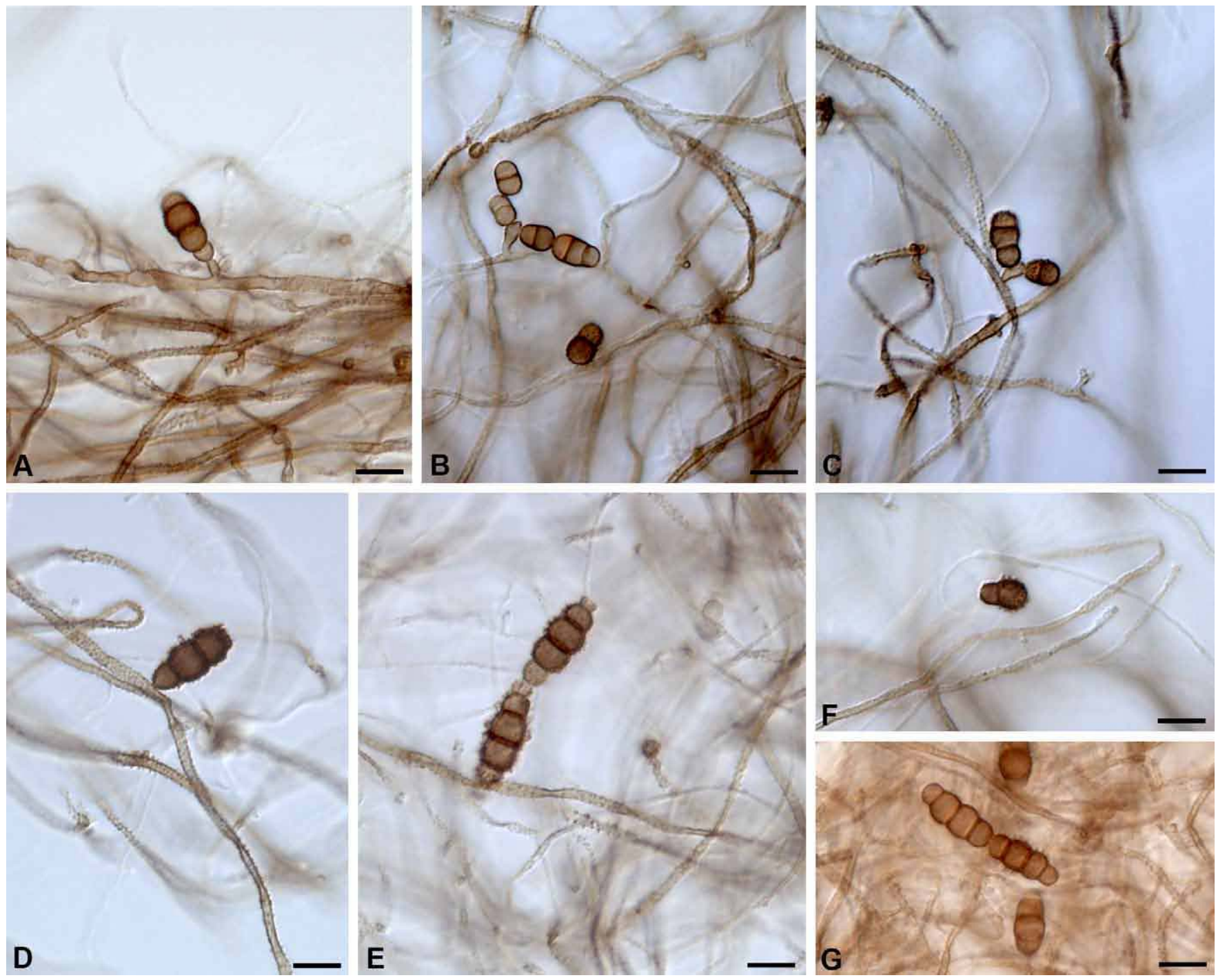

Fig. 6. Bahusandhika caligans (holotype). A-C. Monoblastic and polyblastic conidiogenous cells illustrating immature solitary or catenate conidia. D-G. Mature solitary or catenate conidia. Bars $=10 \mu \mathrm{m}$.

Mar. 1963, S.J. Hughes 4936 (DAOM 96014b - holotype; ILLS 73038 [microscopic preparation] - isotypes).

Description: Colonies on bark effuse, floccose, olivaceous black. Mycelium superficial to immersed, composed of branched, septate, light brown hyphae, 1.5-3 $\mu \mathrm{m}$ wide, occurring singly or in bundles of several parallel filaments. Conidiophores brown, septate, simple or branched with successive, catenate conidiogenous cells, $17-28 \times 3-4.5 \mu \mathrm{m}$, cells of conidiophore cylindrical, $7.5-14.5 \times 3.5-5 \mu \mathrm{m}$. Conidiogenous cells spherical to subspherical, brown, verruculose, monoblastic or polyblastic, $5.5-8(-9) \times 5.5-8 \mu \mathrm{m}$, usually the largest cell at the apex of a chain of cells (conidiophore). Conidia borne singly or in acropetal chains, cylindrical to fusiform, occasionally obpyriform, verrucose, somewhat moniliform, 6-25-septate, constricted at septa, central cells progressively larger towards the centre of conidium, dark brown, end cells lighter brown, $11-142(-200) \times 12-17 \mu \mathrm{m}$.

Additional specimens examined: New Zealand: Auckland District: Piha, on Rhopalostylis sapida, 36.9530 S, 174.4688 E, 31 Jan. 1963, J.M. Dingley \& S.J. Hughes 221 (DAOM 96001, PDD 20495);
Summit of Whitianga Road, $1000 \mathrm{ft}$, Coromandel Peninsula, 36.8484 S, 174.7633 E, 21 Aug. 1963, S.J. Hughes 1164c (DAOM 96041c); on Schefflera digitata, J.M. Dingley [S.J. Hughes 1179] (DAOM 96044, ILLS 73042 [microscopic preparation]); Pareora, on Melicytus ramiflorus, 44.4877 S, 171.2091 E, 21 Mar. 1963, S.J. Hughes 504 (DAOM 96019, ILLS 73039 [microscopic preparation]); Casey's Creek Dam, Hunua, on Schefflera digitata with a Helminthosporium, 37.0782 S, 175.0706 E, J.M. Dingley [S.J. Hughes 320a] (DAOM 96006a, ILLS 73041 [microscopic preparation]).

Notes: The apical cells of the conidia in $B$. hughesii frequently become conidiogenous forming a chain of conidia holoblastically. Like all end cells of the conidia, they are light brown in colour and have thinner walls than the central cells. The resulting chain of conidia give the appearance of a very long conidium which eventually fragments into shorter conidia.

Bahusandhika intercalaris (E.K. Cash \& A.M.J. Watson) Subram., J. Indian Bot. Soc. 35: 469 (1956).

(Fig. 8) 

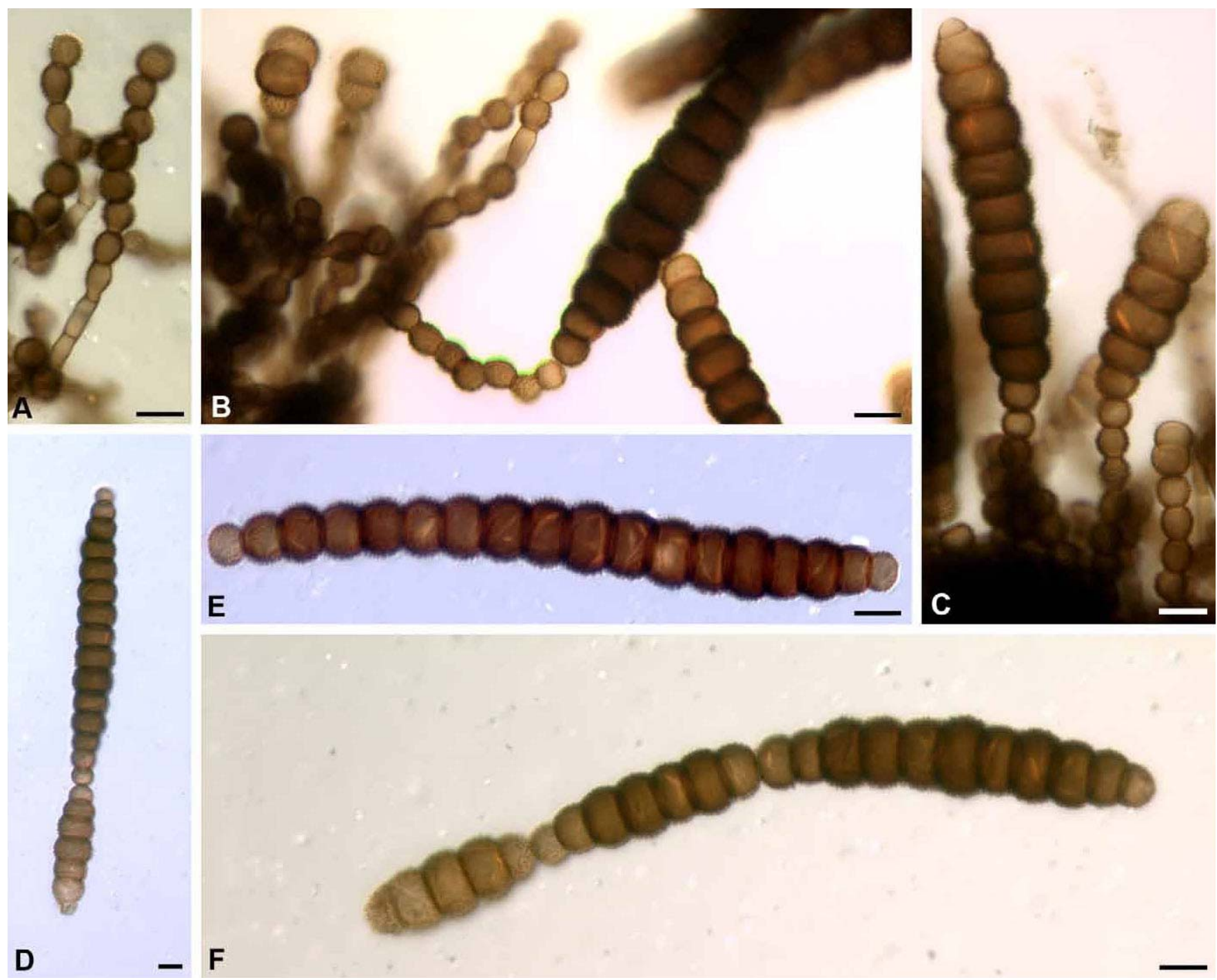

Fig. 7. Bahusandhika hughesii (holotype) A-B. Conidiophores with successive spherical or subspherical conidiogenous cells. C. Conidiogenous cells with conidia developing singly. D-F. Mature conidia. E-F. Catenate conidia. Bars $=10 \mu \mathrm{m}$.

Basionym: Septonema intercalare E.K. Cash \& A.M.J. Watson, Mycologia 47: 744 (1955).

Description: Colonies discrete to effuse, pulverulent, brown to dark brown or black with conidial production. Mycelium composed of septate, brown, extensively branched and net-like hyphae on surface of substrate, 2-3 $\mu \mathrm{m}$ wide. Conidiophores borne terminally or laterally on the hyphae, septate, brown, composed of 1-3 oblong to oval cells, constricted at the septa, $3.5-5.5 \times 2.5 \mu \mathrm{m}$. Conidiogenous cells monoblastic, uniformly light brown, ampuliform to ovoid or rounded, $(2.5-) 3.5-5 \times 2.5-3 \mu \mathrm{m}$, formed singly at the apex of conidiophores or either singly or in groups of 2-3 from the apical cell of a conidium. Conidia thick-walled and smooth, oblong, cylindrical to somewhat fusiform, at times slightly curved, 2-3-septate, rarely 5-septate, slightly constricted at septa, light brown to brown, catenate in simple or branched, acropetal chains, $(11-) 12.5-15.5(-18) \times 4.5-5.5(-6.5) \mu \mathrm{m}$.

Type: Venezuela: intercepted at Brownsville, Texas, on Laelia sp., 30 Oct. 1946, R.A. Alexander [P.Q. 62939] (BPI 428175 - holotype).
Additional specimens examined: Costa Rica: intercepted at San Francisco, California, on Odontoglossum sp., 10 Nov. 1950, Lefebvre \& Thompaon [P.Q. 27438] (BPI 428176 - paratype); Mexico: intercepted at EI Paso, Texas, on Oncidium sphacelatum, 12 Aug. 1948, E. Smith [P.Q. 51249] (BPI 428178 - paratype); intercepted at Brownsville, [Texas], on Oncidium hastatum, 27 Sept. 1957, E.C. Heinrich [P.Q. 79008] (BPI 428177 - paratype); intercepted at El Paso, Texas, on an orchid, 9 Jan. 1978, Aronson \& Ridlehuber [P.Q. 8113] (BPI 428179 - paratype); Panama: Canal Zone: intercepted at San Francisco, California, on Cattleya bowringiana, 29 Nov. 1949, A.S. Johnson [P.Q. 26493] (BPI 428174 - paratype).

Notes: Bahusandhika sundara is close to $B$. intercalaris but differs in having colonies that are greenish black, wider hyphae and longer conidiophores. The two species are similar in morphology and in the size of the conidia and conidiogenous cells. Not having seen the type of $B$. sundara, we are retaining the two species as distinct. 

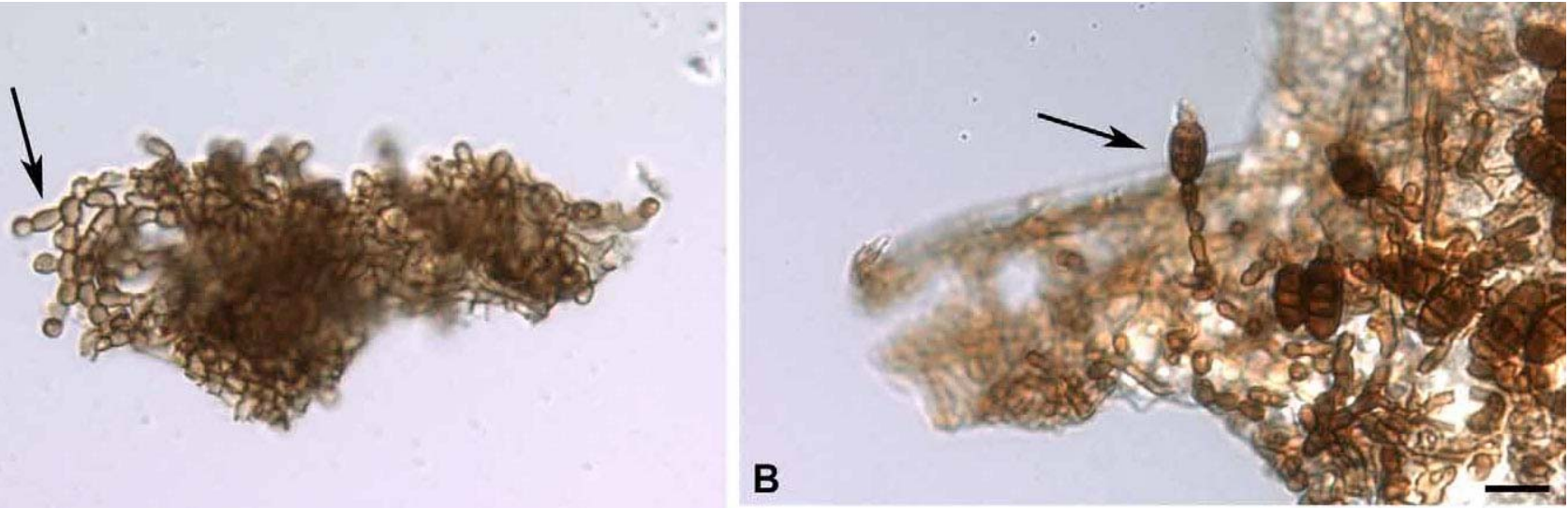

A

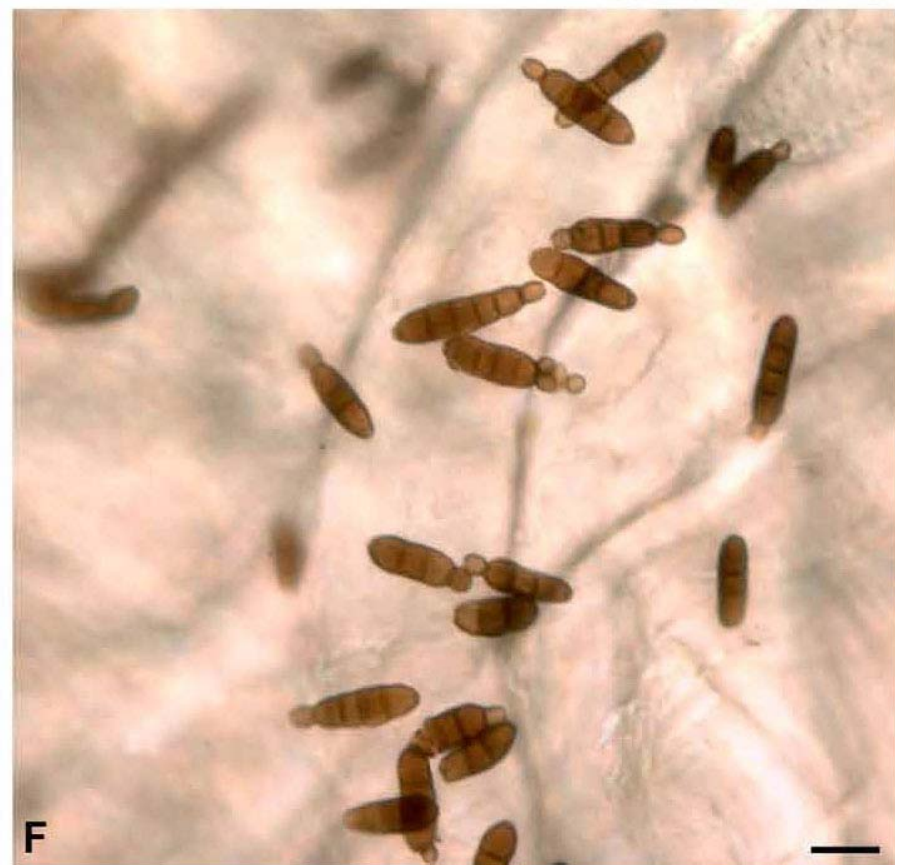

\section{C}
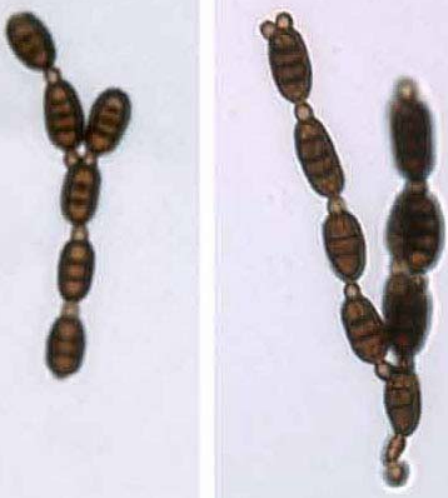

E

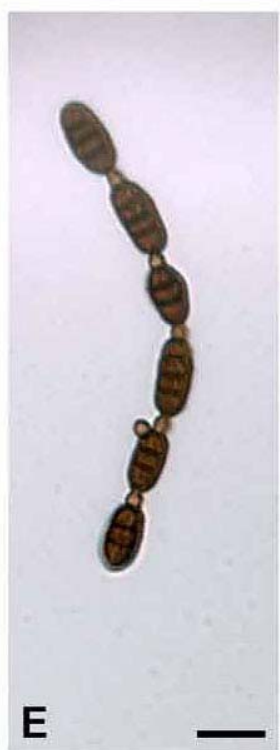

F

Fig. 8. Bahusandhika intercalaris (holotype). A. Extensively branched net-like hyphae with developing conidiophore (arrow). B. Two-celled conidiophore with a conidiogenous cell and a developing conidium. C-E. Chains of mature conidia illustrating the development of conidiogenous cells from the apical cell of conidia. F. Mature conidia. Bars $=10 \mu \mathrm{m}$.

Bahusandhika rhombica (V. Rao \& de Hoog) J.L. Crane \& A.N. Mill., comb. nov.

MycoBank MB815639

(Fig. 9)

Basionym: Torula rhombica V. Rao \& de Hoog, Persoonia 8: 199 (1975).

Description: Colonies on decayed wood effuse, black. Mycelium composed of branched septate hyphae ranging from subhyaline to pale brown or reddish brown. Conidiogenous cells holoblastic, arising terminally or laterally on the hyphae, subhyaline to reddish brown, minutely verruculose, ovoid to pear shaped, sometimes in a series of successive cells. Conidia fusiform-elliptical to rhomboidal, verrucose, catenate, 33-43(-46) $\times$ 11-14(-17) $\mu \mathrm{m}$, 4-7-septate becoming constricted at the septa, central cells reddish brown, becoming progressively enlarged towards the centre, end cells pale to light brown, $3 \mu \mathrm{m}$ long $\times 4.5 \mu \mathrm{m}$ wide.

Type: India: Andhra Pradesh: Balaji, Hyderabad, 17.4174 $\mathrm{N}, 78.4610 \mathrm{E}$, in ligno putrido, in seminario arborum, Sept.
1969, Vasant Rao (K(M) IMI 162.901- holotype; DAOM, ILLS 68205 [microscopic preparations] - isotypes).

Notes: The rhomboid shape of the conidia clearly segregate this species from Bahusandhika caligans and B. terrestris, and the conidiogenous cells appear to be monoblastic. However, all three species in Bahusandhika are similar in that the apical cell of the conidia may become conidiogenous resulting in chains of conidia. Few conidiogenous cells were seen in the type material examined and reference is made to Fig. 1 of the original description of this species by Rao \& de Hoog (1975).

Bahusandhika terrestris (Misra) J.L. Crane, S. Hughes \& A.N. Mill., comb. nov. MycoBank MB815640

(Fig. 10)

Basionym: Torula terrestris Misra, Canad. J. Bot. 45: 367 (1967).

Description: Colonies on Czapek agar composed of branched septate, subhyaline to dark brown, verruculose hyphae. 


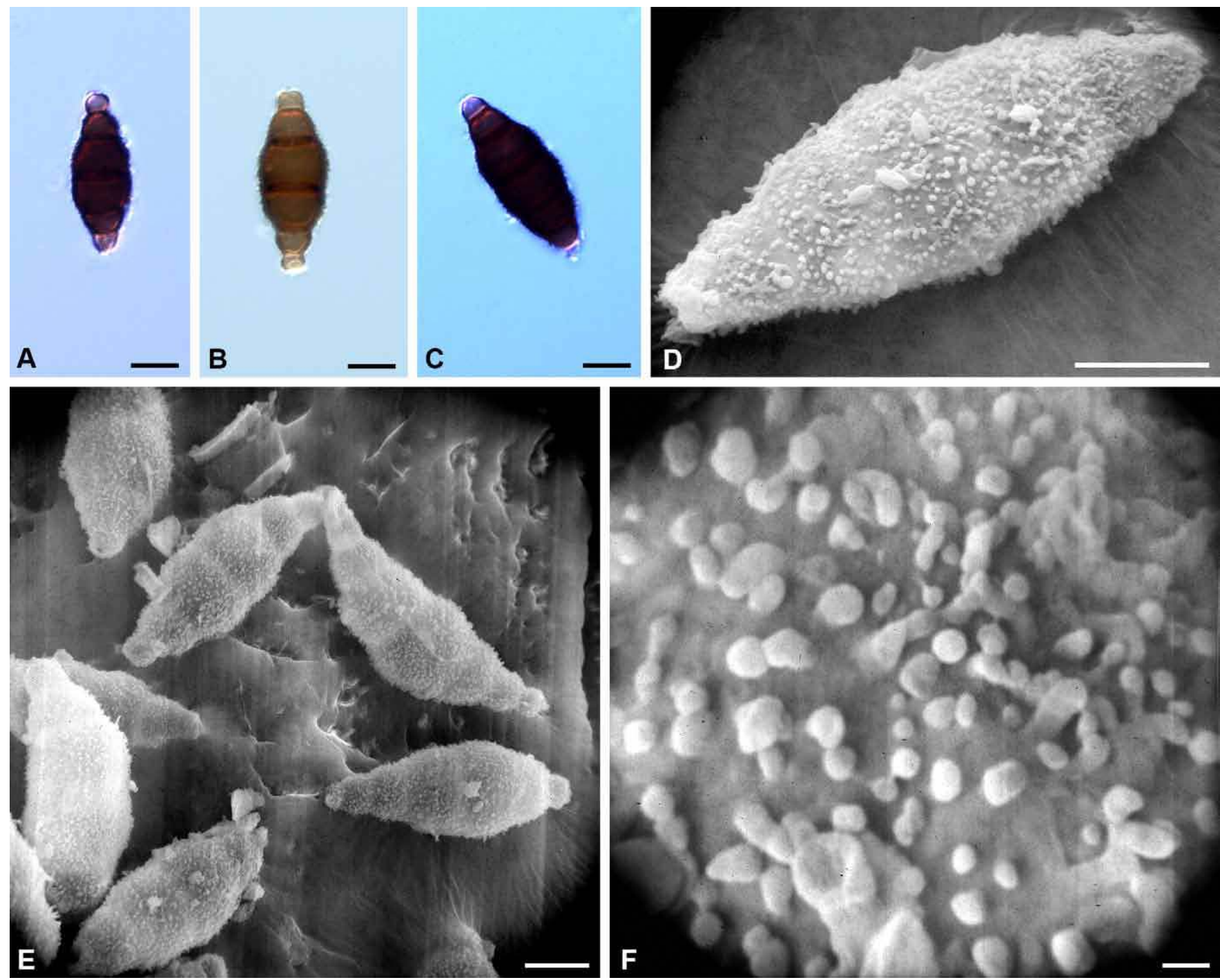

Fig. 9. Bahusandhika rhombica (holotype). A-C. Mature conidia. D-F. SEM micrographs of conidia and verrucae. Bars: $A-E=10 \mu \mathrm{m}, F=1 \mu \mathrm{m}$.

Conidiophores micronematous, verruculose, subhyaline to light brown, producing a terminal conidiogenous cell or reduced to an ovoid-cylindrical stalk cell measuring 4.5$6.5(-7.5) \times 5.5 \mu \mathrm{m}$. Conidiogenous cells light brown, oval, thin-walled, not coronate, produced acropleurogenously on the conidiophore or directly from the hyphae, monoblastic or polyblastic, $5.5-7.5 \times 5.5-6 \mu \mathrm{m}$, sometimes in chains of successive conidiogenous cells. Conidia obovate to somewhat cylindrical, dark brown, thick-walled, verruculose to verrucose, septate, constricted at septa, catenate; septation varies: those with 1-2-septate conidia 14.5-18(20) $\times(5.5-) 7.5-9 \mu \mathrm{m}, 3$-septate conidia 20-25.5(-27) $\times$ 7.5-11 $\mu \mathrm{m}, 4$-septate conidia $27-29(-30) \times(5.5-) 9-13 \mu \mathrm{m}$, and 5-septate conidia, 30-36 × 11-13 $\mu \mathrm{m}$. Conidia with 1-2-septa are somewhat turbinate, 3-5-septa are cylindrical to ellipsoidal; most conidia have pale to light brown, thinwalled, rounded end cells but occasionally conidia have a pale end cell and a dark brown end cell.

Type: India: Uttar Pradesh: Gorakhpur, isolated from soil sample in a sal (Shorea robusta) forest, $26.7605 \mathrm{~N}, 83.3731$ E, Nov. 1961, P.C. Misra (K(M) IMI 93988 - holotype).

Note: Although chains of conidia are rare, we feel this species is best placed in Bahusandhika.

\section{Key to the species of Bahusandhika}


4 (3) Conidia constricted at septa ..... 5

Conidia not constricted at septa

5 (4) Conidia with central cells enlarged and echinulate

6 (4) Conidia obovate-cylindric, verruculose and thick-walled
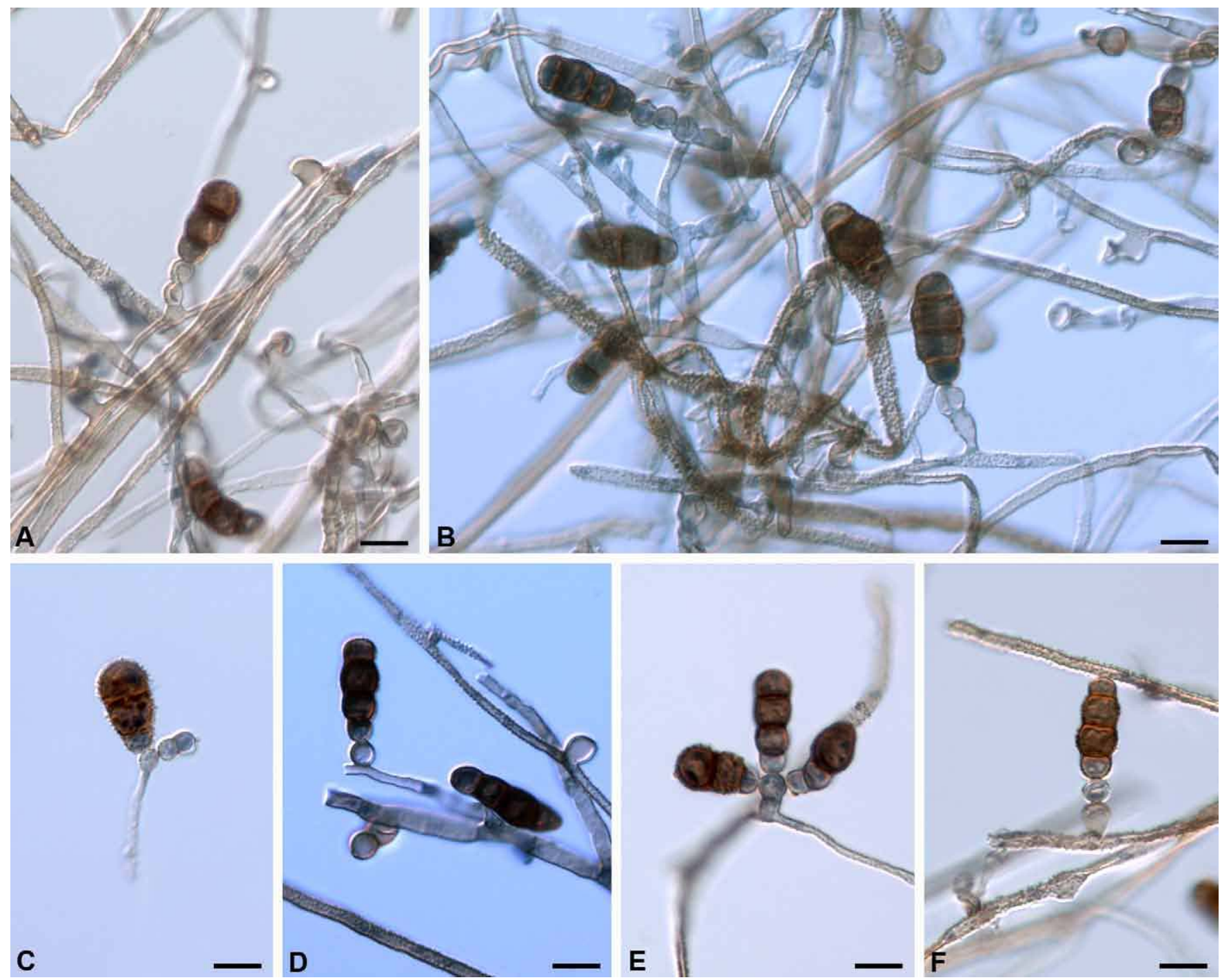

Fig. 10. Bahusandhika terrestris conidiogenesis with mature conidia (holotype). A-B, D, F. Monoblastic conidiogenous cells. C, E. Polyblastic conidiogenous cells. Bars $=10 \mu \mathrm{m}$.

Pseudotorula Subram., J. Indian Bot. Soc. 37: 58 (1958).

Type: Pseudotorula heterospora Subram. 1958.

Synonym: Dwayabeeja Subram., J. Indian bot. Soc. 37: 56 (1958).

Pseudotorula helica Subram. \& Bhat, Kavaka 15: 69 (1989) [“1987"].

(Fig. 11)
Description: Colonies discrete, floccose, black. Mycelium superficial, composed of branched, septate, brown hyphae, $2 \mu \mathrm{m}$ wide. Conidiophores simple or branched arising terminally or laterally on the hyphae, consisting of 1-4 globose, subglobose to cylindrical, light brown cells each terminated by a conidiogenous cell. Conidiogenous cells coronate, dark brown and thick-walled at base, at apex thin-walled and light brown, frequently collapsing and becoming cupulate. Conidia biform with phragmoconidia 

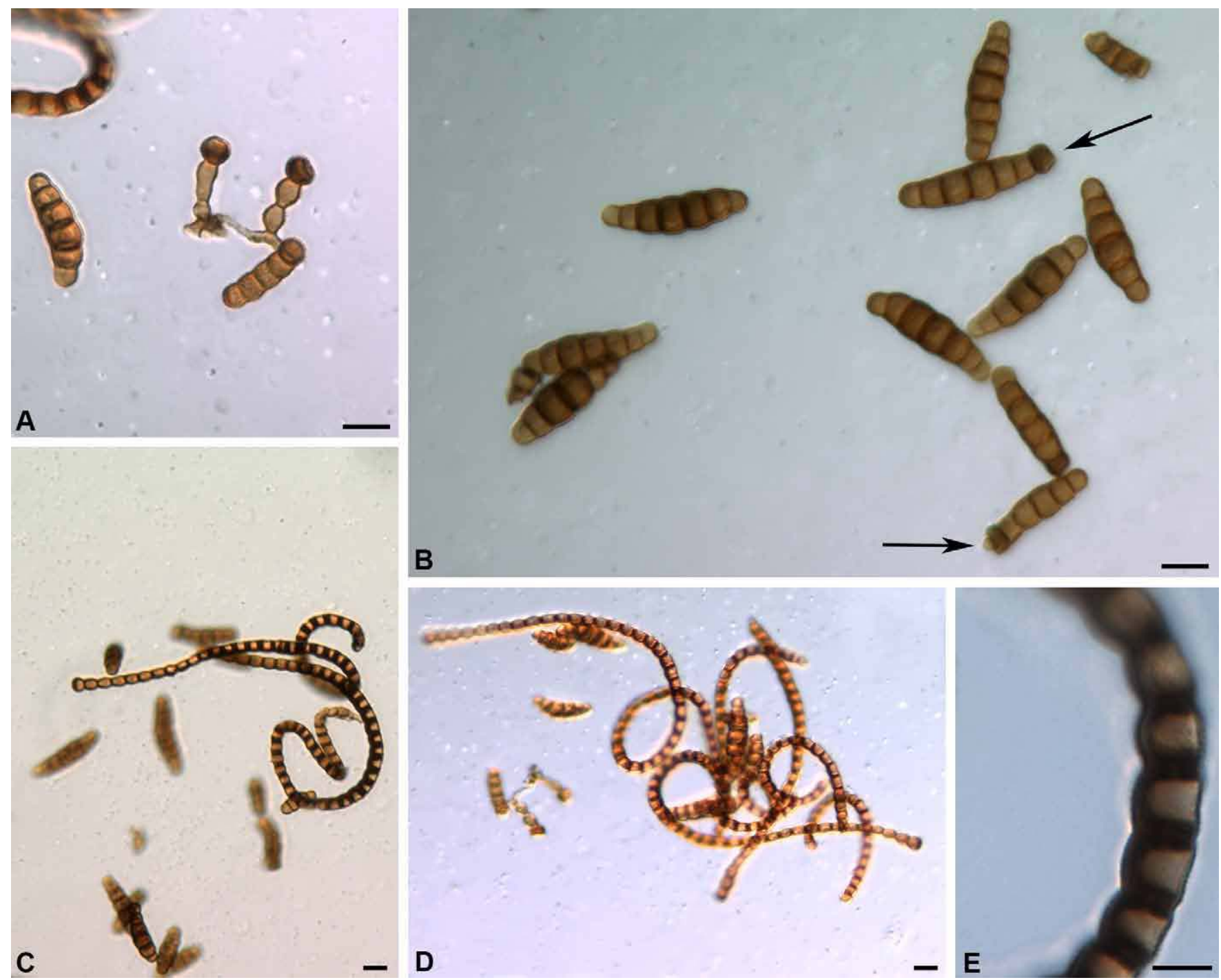

Fig. 11. Pseudotorula helica. A. Conidiophores developed laterally on a hypha and each terminated by a corona cell (holotype). B. Mature phragmoconidia, arrows show corona cells at apex of two conidia (DAOM 96014e). C-D. Scolecoconidia illustrating the helical arrangement and the extensive melanization and periclinal thickening of the wall (holotype \& DAOM 96014e). E. Enlargement of cells of a scolecoconidium illustrating periclinal thickening of the wall and melanization of the wall and septa (DAOM 96014e). Bars: A-D = $10 \mu \mathrm{m}, \mathrm{E}=5 \mu \mathrm{m}$.

and scolecoconidia. Phragmoconidia borne singly or in chains, cylindrical, fusiform or slightly curved, constricted at septa, usually with $4-7$ thick, dark septa, (17-)20-28($38) \times 6-9 \mu \mathrm{m}$, occasionally short-cylindrical conidia with 1-2-septa were noted measuring 9-10 × 3.5-5.5 $\mu \mathrm{m}$; terminal cell of many phragmoconidia become coronate and conidiogenous. Scolecoconidia sigmoid, curved to hooked but mostly helical, light brown, with 10-23-septa, 42-250 × $3.5-6 \mu \mathrm{m}$; most characteristic is the extensive melanization and concurrent periclinal thickening of the wall that occurs partially or for the entire length on one side of the conidium, the melanization extends into the septa giving them a thick dark brown appearance.

Type: India: Tamil Nadu: Berijam, Kodaikanal, Pulnney Hills, on unidentified dead twigs, 10.2033 S, 77.4406 E, 2 Feb. 1981, C.V. Subramanian (FFSI 4540 - holotype).

Additional specimens examined: New Zealand: Coromandel: Kauaeranga Valley, Thames, on [old decayed stems] of Schefflera digitata, 37.1487 S, 175.5829 E, 4 Sept. 1963, J.M. Dingley 1267 (DAOM 159749a, PDD 21491); Bay of Plenty, Mamaku State Forest, on Coprosma australis, 36.8484 S, 174.7633 E, 23 Mar. 1963, S.J. Hughes 493a (DAOM 96014e, PDD 20656, ILLS 73040 [microscopic preparation]).

Notes: The spiral-shape, extensive melanization and thickening in the periclinal wall of the scolecoconidia was noted by Subramanian (1987) in the collection from India. The New Zealand collections differ from the type description in the scolecoconidia being more helical with to 105 septa vs 45 septa in the Indian collection. The phragmoconidia of the Indian and New Zealand collections are similar in morphology and measurements.

Dwayabeeja aethiopica superficially resembles Pseudotorula helica in having conidia that are biform with the scolecosporous conidia heavily melanized on the periclinal wall. However the phragmoconidia are reported as solitary, while those of $P$. helica are catenate. 

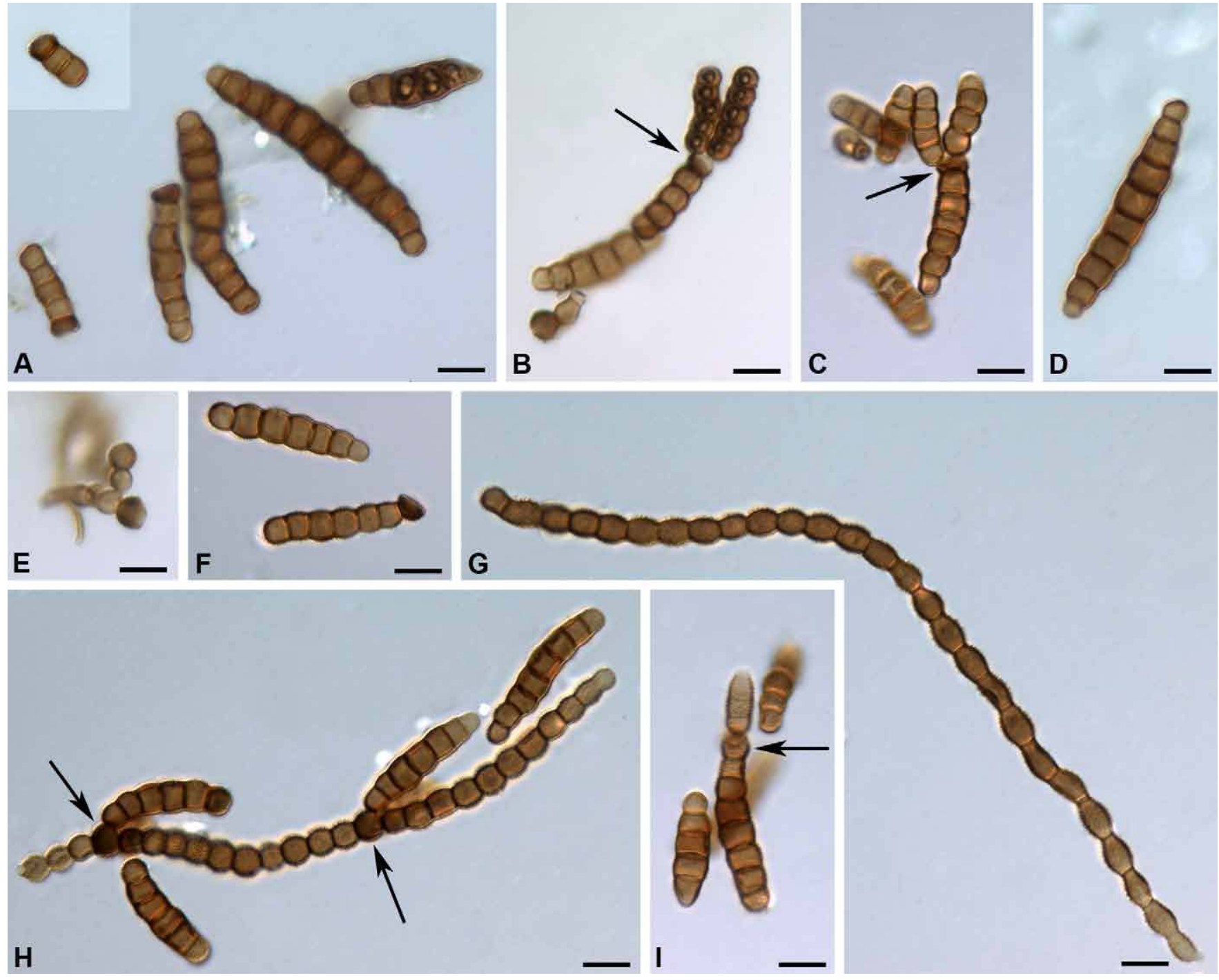

Fig. 12. Pseudotorula sundara (holotype). A, D, F. Phragmoconidia. A. inset a 2-septate conidium. B-C. Phragmoconidia in chains from polyblastic corona cells (arrows). E. Conidiophore with a corona cell. G. Scolecoconidium. H. Scolecoconidium with developing phragmoconidia from corona cells (arrows). I. Phragmoconidium from a monoblastic corona cell (arrow) at apex of a conidium. Bars $=10 \mu \mathrm{m}$.

\section{Pseudotorula sundara (Subram.) J.L. Crane \& A. Mill., comb. nov. \\ MycoBank MB815641}

(Fig. 12)

Basionym: Dwayabeeja sundara Subram., J. Indian Bot. Soc. 37: 56 (1958).

Description: Colonies black, dry, floccose, discrete. Mycelium composed of smooth, septate, brown hyphae, 1-3 $\mu \mathrm{m}$ wide. Conidiophores simple or branched, light brown, composed of 1-4 cylindrical to ovoid cells measuring 4.5-6 $\mu \mathrm{m}$, borne terminally or laterally on the hyphae. Conidiogenous (corona) cells developing on conidiophores or the apical cell of a phagmoconidium or between cells of a scolecoconidium, monoblastic or polyblastic, subglobose to globose, verruculose, thick-walled and heavily melanized at base, thin-walled and light brown at apex, 5.5-8 $\mu \mathrm{m}$, the apex collapsing to give a coronate appearance. Conidia biform with phragmoconidia and scolecoconidia. Phragmoconidia borne singly or in chains, brown, cylindrical to fusiform or sigmoid, constricted at septa, septation varies from 2-10-septa, with 2-septate conidia 6-7 $\times 3 \mu \mathrm{m}$ and 10-septate conidia 30-33 × 5-5.5 $\mu \mathrm{m}$. Scolecoconidia straight, sigmoid or arched, brown, thick-walled, at base 3-6 $\mu \mathrm{m}$, at apex tapering, light brown to subhyaline, $3 \mu \mathrm{m}$ wide, measured length $135-230 \mu \mathrm{m}$ but up to $420 \mu \mathrm{m}$ reported in original description.

Type: India: Madras State: Nilgiris Region, Sim's Park, Coonoor, on dead leaf rachis of Phoenix canariensis, 11.3530 N, 76.7959 E, 22 Nov. 1957, C.V. Subramanian (DAOM 185052 [ex IMI 114639 ex MUBL 1924] - isotype).

Additional specimen examined: New Zealand: Auckland District: Mamaku State Forest, on Coprosma australis, 36.8484 S, 174.7633 E, 22 Mar. 1963, S.J. Hughes (DAOM 96014a, PDD 20656, ILLS 73043).

Notes: Dwayabeeja was described by Subramanian (1958) with $D$. sundara as the type species. An examination of isotype material and a specimen from New Zealand shows that some of the phragmoconidia are formed in chains 
(Fig. 12A-B, D). We, therefore, select Pseudotorula over Dwayabeeja and transfer $D$. sundara to Pseudotorula; both generic names were published in the same paper and have equal priority and this selection is made in accordance with Art. 11.5. It was also noted that some of the cells in the scolecoconidia may become coronate and conidiogenous giving rise to phragmoconidia (Fig. $12 \mathrm{H}-\mathrm{I}$ arrows).

Four species were described in Dwayabeeja, and of these $D$. aethiopica and $D$. cubensis, which we were unable to examine, will require placement in a new genus. Dwayabeeja graminis was transferred to Bahuchaskala as B. graminis. Not being willing to establish a new genus without examining the two remaining species, we have used "Dwayabeeja" in the generic key.

\section{Simmonsiella J.L. Crane \& A.N. Mill., gen. nov. MycoBank MB815642}

Etymology: Honouring Emory Guy Simmons (1920-2013), distinguished mycologist and mentor to a younger generation.

Type: Simmonsiella ndjilensis (É. Kiffer) J.L. Crane \& A.N. Mill. 2016.

Description: Colonies effuse, brown to grey-brown, composed of branched, septate, smooth or echinulate hyphae. Conidiogenous cells discrete, borne terminally or laterally on the hyphae, thin-walled, subhyaline, subcylindric to obovate, monoblastic or polyblastic. Phragmoconidia thick-walled, verrucose to echinulate, light brown to dark brown, becoming darker with age, with black bands at the septa, borne singly or in chains. Catenate conidia may be formed by an apical cell of a conidium becoming conidiogenous and blastically giving rise to a conidium or more frequently, the apical cell of a conidium blastically forms a light brown, intercalary hypha which in turn forms blastically a conidium, by repetition of this process, a series of conidia separated by intercalary hyphae are formed.

\section{Simmonsiella ndjilensis (É. Kiffer) J.L. Crane \& A.N. Mill., comb. nov. \\ MycoBank MB815643}

(Fig. 13)

Basionym: Torula ndjilensis É. Kiffer, Naturaliste Canad. 100: 257 (1973).

Description: Colonies effuse, brown to grey-brown, composed of branched, septate, smooth or echinulate hyphae, 2.5-6 $\mu \mathrm{m}$ wide. Conidiogenous cells discrete, borne terminally or laterally on the micronematous hyphae, thinwalled, subhyaline, subcylindrical to obovate, monoblastic or polyblastic, 5.5-7.5(-9) × 5.5-6.5 $\mu \mathrm{m}$. Phragmoconidia thick-walled, verrucose to echinulate, light to dark brown, becoming darker with age, 3-5(-7)-septate, with black bands at the septa, borne singly or in chains by intercalary hyphae, 37-46.5 × 13-18(-20) $\mu \mathrm{m}$. Intercalary hyphae, septate, constricted at septa, subhyaline to light brown, verrucose to echinulate, 5.5-7.5 $\mu \mathrm{m}$ wide.

Type: Zaire: Kinshasa, Gignitur e scobibus lignosis insuper humum. [du sol de la station de la Ndjili (Kinshasa, Republique du Zaire), 4.3316 S, 15.3138 E], 26 Nov. 1972, F. Mangeot \& É. Kiffer s.n. (K(M) IMI 171803 - holotype; ILLS 68272 [microscopic preparation] - isotype).

Notes: In Simmonsiella ndjilensis, catenate conidia may be formed by an apical cell of a conidium becoming conidiogenous and blastically giving rise to a conidium or, more frequently, the apical cell of a conidium blastically forms a pale brown, intercalary hypha which in turn forms a conidium blastically. By repetition of this process, a series of conidia separated by intercalary hyphae are formed. This process was clearly illustrated in Fig. 1 of Kieffer (1973). Simmonsiella is similar to Intercalarispora (Schoknecht \& Crane 1983) in producing intercalary conidia, but differs from the latter in being phragmoseptate and the conidia of Intercalarispora are dictyoseptate.

Torula verrucospora (P. Mathur \& G. Singh) B. Sutton, Mycol. Papers 167: 67 (1993).

(Fig. 14)

Basionym: Pseudotorula verrucospora P. Mathur \& G. Singh, Indian Phytopath. 17: 306 (1965) [“1964”].

Type: India: Rajasthan, Budha Pushkar, Ajmer, Oct. 1961, G. Singh (K(M) IMI176874 - holotype)

Synonyms: Torula herbarum f. quaternella Sacc., Annl. Mycol. 11: 556 (1913).

Bahusandhika compacta Rikhy et al., Rev. Mycol. 38: 91 (1975).

Type: India: Delhi, on Triticum sp., 28.6139 N, $77.2090 \mathrm{E}$, Dec. 1972, K.G. Mukerj (K(M) IMI 176874 - holotype; ILLS 73044 [microscopic preparation]).

Notes: Sutton (1993) examined the holotype of Pseudotorula verrucospora and found it synonymous with $T$. herbarum f. quaternella. Based on the catenate, 3-septate conidia, conidial width and the prominence of this form in the tropics, he elevated f. quaternella to species rank using the epithet verrucospora which has priority at species rank. An examination of the holotype of $B$. compacta (Fig. 14) indicates that it belongs in the genus Torula and is synonymous with $T$. verrucospora based on conidial development, morphology, septation and the tropical habitat.

\section{Key to Torula and similar genera}

1 Coronate conidiogenous cells (corona cells) present 2

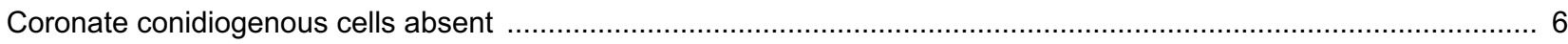

2 (1) Corona cells terminal, solitary or catenate 
3 (2) Conidia uniform 4

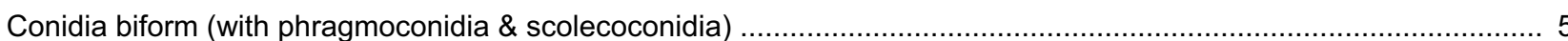

4 (3) Conidia catenate Torula

Conidia solitary Bahusaganda

5 (3) Phragmoconidia solitary "Dwayabeeja" Phragmoconidia catenate Pseudotorula

6 (1) Conidia solitary

Polyschema

Conidia catenate

Simmonsiella

7 (6) Conidial chains usually with intercalary hyphae Bahusandhika

Conidial chains lacking intercalary hyphae

\section{ACKNOWLEDGMENTS}

The assistance of the curators and managers of the following institutions is greatly appreciated: BPI, CBS, DAOM, ILL, ILLS, K (IMI), IMUR, K, L, NY, NYS, and W. We owe a debt of gratitude to Stanley J. Hughes for the loan of his New Zealand collections of fungi pertinent to this study; on a more personal note, J.L.C. is grateful to him for being a mentor and kindling his interest in hyphomycetes. We appreciate the constructive review of the first draft of this paper by Keith A. Seifert.

\section{REFERENCES}

Bhat DJ (1985) Two new species from Ethiopia. Proceedings of the Indian National Academy of Science, B 94: 269-272.

Crane JL, Schoknecht JD (1977) Revision of Torula species. Rutola, a new name for Torula graminis. Canadian Journal of Botany 55: 3013-3019.

Crous PW, Carris LM, Giraldo A, Groenewald JZ, Hawksworth DL, et al. (2015) The Genera of Fungi - fixing the application of the type species of generic names - G 2: Allantophomopsis, Latorua, Macrodiplodiopsis, Macrohilum, Milospium, Protostegia, Pyricularia, Robillarda, Rotula, Septoriella, Torula, and Wojnowicia. IMA Fungus 6: 163-198.

Ellis MB (1971) Dematiaceous Hyphomycetes. Kew: Commonwealth Mycological Institute.

Ellis MB (1976) More Dematiaceous Hyphomycetes. Kew: Commonwealth Mycological Institute.

Hughes SJ (1953) Conidiophores, conidia, and classification. Canadian Journal of Botany 31: 577-659.

Hughes SJ (1958) Revisiones Hyphomycetum aliquot cum appendice de nominibus rajiciendis. Canadian Journal of Botany 36: 561726.

Kiffer É (1973) Contribution à l'étude de la microflore fongique du Congo III. Torula ndjilensis sp. nov. et Balanium africanum sp. nov. Naturaliste Canadiene 100: 257-263.
Mason EW (1941) Annotated account of fungi received at the Imperial Mycological Institute. List 2. Fasc. 3 (special part). Commonw. Mycological Papers 5: 1-144.

Mercado Sierra A (1980) Nueva especie de Dwayabeeja (Fungi Imperfecti) de Cuba. Acta Botanica Cubana 3: 1-4.

Rao V, Rao D (1972) A new species of Bahusandhika from India. Indian Phytopathology 25: 289-291.

Rao V, De Hoog G (1975) Some notes on Torula. Persoonia 8: 199206.

Schoknecht JD, Crane JL (1983) Additional hyphomycetes from freshwater swamps and hammocks. Canadian Journal of Botany 61: 2243-2247.

Seifert K, Morgan-Jones G, Gams W, Kendrick B (2011) The Genera of Hyphomycetes. [CBS Biodiversity Series no. 9.] Utrecht: CBS/ KNAW Fungal Biodiversity Centre.

Singh SN, Chaudhary PN, Sarbhoy AK (1974) Dematiaceous hyphomycetes from India II. Indian Phytopathology 27: 634-636.

Subramanian CV (1958) Hyphomycetes V. Journal of the Indian Botanical Society 37: 47-64.

Subramanian CV (1971) Hyphomycetes: An account of Indian species except Cercosporae. New Delhi: Indian Council of Agricultural Research,.

Subramanian CV (1977) Revisions of hyphomycetes-I. Kavaka 5: 93-98.

Subramanian CV, Srivastava V (1994) Hyphomycetes from the Kumaon Himalayas: Bahusaganda sundara. Proceedings of the Indian National Academy of Science, B 60: 277-280.

Sutton BC (1993) Mitosporic fungi from Malawi. Mycological Papers 167: 1-93.

Wu C-G, Tseng H-Y, Chen Z-C (1982) Fungi inhabiting Schoenoplectus triqueter (L.) Palla. Taiwania 27: 35-38. 